\title{
Analisis Penguatan Fungsi Badan Permus yawaratan Desa (BPD) di Desa Karyamukti Kabupaten Gorontalo
}

\author{
Program Studi Ilmu Pemerintahan Universitas Gorontalo \\ suaibnapir@yahoo.co.id
}

\begin{abstract}
The aim of this research is to investigate the function empowerment of the Village Deliberation Agency (VDA) in Karyamukti Village, Gorontalo Regency. This research is tring to investigate the function empowerment of the Village Deliberation Agency (VDA) in Karyamukti Village, Gorontalo Regency. The research method was the qualitative method with the institutional approach, and the research type was descriptive-qualitative in character. The data collections is doing by interviews, observation, and documentation. The research informants were the Chairman and the Vice-Chairman of the Village Deliberation Agency, the Village Chief, and the Community Members. The research results revealed that, First, the VDA has not been fullest accommodating and channeling the aspirations of society because VDA is using his own way system division of region and all its members are accountable to their respective territories in receiving the community's aspirations. Second, the VDA has made the draft, discuss and instituted regulations of the village along the village chief Karyamukti, but has not shown maximum results due to a lack of human resources capabilities and less effective organization of VDA in manufacturing process of the regulation of the Karyamukti village. Third, the VDA was already conducting surveillance performance village chief Tallambalao but has not shown the maximum supervision because of the limited regulation which became guidelines for VDA and the lack of human resources capabilities of members of VDA in the surveillance.
\end{abstract}

Keywords: VDA; aspirations; village regulation; control.

\section{ABSTRAK}

Tujuan penelitian ini adalah untuk menyelidiki fungsi pemberdayaan Musyawarah Desa (VDA) di Desa Karyamukti, Kabupaten Gorontalo. Penelitian ini bertujuan untuk menginvestigasi fungsi pemberdayaan Musyawarah Desa (VDA) di Desa Karyamukti, Kabupaten Gorontalo. Metode penelitian adalah metode kualitatif dengan pendekatan institusional, dan tipe penelitiannya bersifat deskriptifkualitatif. Pengumpulan data dilakukan dengan wawancara, observasi, dan dokumentasi. Informan penelitian adalah Ketua dan Wakil Ketua Badan Musyawarah Desa, Kepala Desa, dan Anggota Masyarakat. Hasil penelitian mengungkapkan bahwa, Pertama, VDA belum sepenuhnya mengakomodasi dan menyalurkan aspirasi masyarakat karena VDA menggunakan sistem pembagian wilayahnya sendiri dan semua anggotanya bertanggung jawab kepada wilayah masing-masing dalam menerima aspirasi masyarakat. Kedua, VDA telah membuat rancangan, membahas dan menetapkan peraturan desa di sepanjang kepala desa Karyamukti, tetapi belum menunjukkan hasil yang maksimal karena kurangnya kemampuan sumber daya manusia dan organisasi VDA yang kurang efektif dalam proses manufaktur dari peraturan tersebut. Desa Karyamukti. Ketiga, VDA sudah melakukan pengawasan kinerja kepala desa Tallambalao tetapi belum menunjukkan pengawasan maksimal karena peraturan yang terbatas yang menjadi pedoman untuk VDA dan kurangnya kemampuan sumber daya manusia anggota VDA dalam pengawasan.

Kata Kunci: VDA; aspirasi; peraturan desa; kontrol. 


\section{PENDAHULUAN}

Perubahan mendasar dalam pengaturan desa adalah munculnya Badan Permusyawaratan Desa (BPD) yang merupakan lembaga tersendiri dan memiliki fungsi yang sangat luas. Pada tahun 1955 terbentuk lembaga desa yang berfungsi merencanakan segala kebutuhan desa bersama-sama dengan perangkat desa dengan sebutan Badan Perencanaan Pemerintah Desa (Bappensa). Nama ini berubah menjadi Badan Musyawarah Desa (Bamudes), berubah lagi menjadi Lembaga Musyawarah Desa (LMD) pada UU No 5/1979, lahirnya UU No 22/1999 berubah menjadi Badan Perwakilan Desa (BPD). Dalam UU No32/2004 dan UU No 12/2008 BPD menjadi Badan Permusyawaratan Desa (BPD). Perbedaan yang substansial antara LMD dan BPD ditinjau dari aspek fungsi dan Yuridis formal, yaitu LMD hanya memiliki fungsi legislasi, sementara BPD selain berfungsi legislasi juga berfungsi mengawasi pemerintah desa, dan juga menampung dan menyalurkan aspirasi masyarakat.

Pembahasan anggaran pendapatan dan belanja desa dimainkan oleh Badan Perwakilan Desa berdasarkan kemauan dan proses politik. Pada Tahun 2010 sampai tahun 2014 APBDes di desa Karyamukti Kabupaten Gorontalo dengan total $\mathrm{Rp} 1.164 .937 .168,15$, yang dikelola secara otonomi oleh pemerintahan desa. Alokasi dana Desa sebagaimana UU No 6 Tahun 2014 didalam pasal 72 ayat (2) mengatur pula keuangan desa paling sedikit 10\% (sepuluh perseratus) dari dana perimbangan yang diterima Kabupaten/Kota dalam Anggaran Pendapatan dan Belanja Daerah setelah dikurangi Dana Alokasi Khusus. Selain potensi keuangan juga terdapat potensi sumber daya alam, seperti tambang galian c, pariwisata, air bersih dan pertanian. Oleh karena itu penguatan fungsi Badan Permusyawaratan Desa dalam mengelola APBDes merupakan langkah strategis yang perlu dilakukan. Penyusunan APBDes mengatur alokasi belanja pemerintah desa lebih banyak digunakan untuk menggerakkan pemerintah desa daripada digunakana pada masyarakat desa. Ini menunjukkan bahwa bahwa penggunaan dana desa belum dapat memecahkan masalah-masalah kemiskinan, infrastruktur, peningkatan pendidikan dan kesehatan. Padahal APBDes dapat dimanfaatkan untuk menciptakan kesejahteraan masyarakat. Diperlukan upaya BPD untuk mengatur anggaran dengan baik sehingga penggunaan anggaran efektif dan efisiensi.

Menurut Fauzan (2010), peranan Badan Permusyawaratan Desa dalam Proses dan Penyususnan Preaturan Desa masih lemah karena dipengaruhi faktor Rendahnya SDM anggota BPD dibidang hukum, kurangnya bimbingan teknis dari pemerintah daerah dalam bidang legislasi, budaya hukum masyarakat rendah, dan adanya kepentingan politik. Kusandajani (2008), menyatakan bahwa proses pengambilan keputusan dilakukan melalui proses musyawarah antara BPD, kepala Desa, dan masyarakat. Proses itu dilakukan setiap tahun dan dilaksanakan dibalai desa melalui musyawarah pembangunan desa (Musbangdes). Musbangdes bertujuan untuk merumuskan peraturan desa Tallambalao.

Sementara Svein (2009), menyatakan bahwa tolok ukur baik atau buruknya sebuah substansi legislasi dapat dianalisi dengan empat kategori, yaitu Kriteria Moral (Moral Criteria) Menilai baik buruknya suatu produk legislasi dari kategori moral secara umum. Kriteria Politik (Political Criteria) menilai substansi peraturan perundang-undangan secara politik. Kriteria Hukum (Legal Criteria) menilai suatu produk legislasi dari aspek hokum. Ketidakharmonisan dalam 
Praktek (Practical Disharmonie) milhat sebuah situasi dimana beberapa produk hukum secara hukum tidak bertabrakan akan tetapi sebenarnya saling menegaskan tujuan dari pengaturan antar produk hukum tersebut. Badan Permusyawaratan Desa memiliki peran penting didalam mengatur potensi di desa Karyamukti.

BPD sebagai lembaga politik yang strategis di pedesaan dapat menciptakan chek and balance yang kuat dalam proses pemerintahan desa guna mewujudkan kesejahteraan maseyarakat desa. Fungsi BPD mempunyai peran yang strategis dalam penyelengaraan pemerintahan desa dan pembangunan desa. Kemajuan suatu desa dipengaruhi kuat oleh kinerja BPD dalam proses politik dalam penyelenggaraan pemerintahan. Oleh karena itu penguatan fungsi Badan Permusyawaratan Desa di desa Karyamukti merupakan suatu hal yang sangat menarik untuk dikaji. Tujuan penelitian adalah untuk mengetahui penguatan fungsi Badan Permusyawaratan Desa di desa Karyamukti Kabupaten Gorontalo.

\section{KAJIAN TEORI}

Dalam Pasal 55 Undang-undang Nomor 6 tentang Desa Tahun 2014 bahwa Badan Permusyawaratan Desa mempunyai fungsi membahas dan menyepakati rancangan peraturan desa bersama kepala desa, menampung dan menyalurkan aspirasi masyarakat Desa, serta melakukan pengawasan kinerja Kepala Desa. Menurut Wulandari (2011), menyatakan peranan BPD telah melaksanakan tugas pokok dan fungsinya dalam menetapkan peraturan desa bersama kepala desa, menampung dan menyalurkan aspirasi walaupun belum secara sepenuhnya semua aspirasi dijadikan peraturan desa. Salim (2012), peranan BPD telah melaksanakan tugas pokok dan fungsinya dalam menetapkan peraturan desa bersama kepala desa, menampung dan menyalurkan aspirasi walaupun belum sepenuhnya semua aspirasi dijadikan peraturan desa. BPD merupakan suatu organisasi ditingkat desa yang berada dalang lingkup sosial yang segala tindakannya memiliki tujuan tertentu.

Menurut Scott (2008), menyatakan bahwa institusi berada pada lingkup struktur social, memiliki elemen-elemen simbolis, aktifitas sosial, dan sumber daya materil. Keberadaan institusi diperlukan sebagai seperangkat proses yang dicirikan dengan elemen-elemen regulatif, normatif dan kultur kognitif yang syarat dengan perubahan. Meskipun unsur-unsur utama dari institusi adalah rules, norms, and cultural benefit, konsep institusi juga menyangkut asosiasi perilaku dan sumber daya materil. Dengan demikian pengertian institusi ditentukan oleh batasan legal, procedural, moral dan cultural yang memiliki legitimasi. Tidak hanya menyangkut property or social order, tetapi juga sebagai proses intitusionalisasi maupun deintitusionalisasi.

Proses institusional dalam pembuatan kebijakan ditingkat desa menurut Kusandajani (2008), menyatakan bahwa proses pengambilan keputusan dilakukan melalui proses musyawarah antara BPD, kepala desa, dan masyarakat. Proses itu dilakukan setiap tahun dan dilaksanakan dibalai desa melalui musyawarah pembangunan desa (musbangdes). Musbangdes bertujuan untuk merumuskan peraturan desa Tallambalao. Peraturan Desa adalah produk hukum tingkat desa yang ditetapkan melalui proses politik oleh Kepala Desa bersama Badan Permusyawaratan Desa dalam rangka penyelenggaraan pemerintahan desa. Peraturan desa merupakan penjabaran lebih lanjut dari 
peraturan perundang-undangan yang lebih tinggi dengan memperhatikan kondisi sosial budaya masyarakat desa setempat.

Natabaya (2007), menyatakan bahwa menilai kualitas peraturan perundangundangan harus dilihat dari hulu sampai hilir. Disamping itu peraturan perundang-undangan adalah sebuah produk politik yang mengandung dua makna. Makna pertama adalah politik dalam arti kebijakan, yakni peraturan yang mengikat pembentukan peraturan perundang-undangan dan yang kedua politik dalam artian politik praktis. Tuori (2009), membaginya dalam tiga bentuk rasionalitas yaitu Object Rationality, Internal Rationality dan Normatif Rationality. Object rationality adalah memastikan bahwa legislasi mampu menjalankan fungsi sosialnya, misalnya dalam mencapai tujuan bersama dan menjadi media integrasi sosial. Internal Rationality menekankan kepada koherensi dan konsistensi pada sistem hukum, dan yang terakhir normatif rationality terkait dengan legitimasi dari legislasi tersebut. Sedangkan Wasistiono \& Tahir (2007), melihat bahwa peraturan desa merupakan penjabaran dari peraturan perundang-undangan yang lebih tinggi dengan memperhatikan kondisi sosial dan budaya masyarakat desa setempat.

Peraturan perundang-undangan bertujuan untuk menguatkan organisasi dalam membangun masyarakat. Atmosoeprapto dalam Nogi (2005), mengemukakan bahwa penguatan organisasi BPD diakibatkan oleh faktor internal dan faktor eksternal. Faktor eksternal, teridiri dari: pertama faktor politik, yaitu berhubungan dengan keseimbangan kekuasaan Negara yang berpengaruh pada keamanan dan ketertiban, yang akan mempengaruhi ketenangan organisasi BPD desa Tallambalao untuk bekerja secara maksimal. Kedua faktor ekonomi, yaitu tingkat perkembangan ekonomi yang berpengaruh pada tingkat pendapatan masyarakat sebagai daya beli untuk menggerakkan sektor-sektor lainnya sebagai suatu system ekonomi yang lebih besar. Ketiga faktor social, yaitu orientasi nilai yang berkembang dimasyarakat, yang mempengaruhi pandangan mereka terhadap etos kerja yang dibutuhkan bagi peningkatan kinerja organisasi BPD. Sementara faktor internal, pertama tujuan organisasi BPD, yaitu apa yang ingin dicapai dan apa yang ingin diproduksi oleh suatu organisasi. Kedua struktur organisasi BPD, sebagai hasil desain antara fungsi yang akan dijalankan oleh unit organisasi dengan struktur formal yang ada. Ketiga sumber daya manusia Anggota BPD, yaitu kualitas dan pengelolaan anggota organisasi sebagai penggerak jalannya organisasi secara keseluruhan. Keempat system, yaitu bagian-bagian suatu organisasi dalam pola kerja yang baku dan menjadi satu kesatuan organisasi yang bersangkutan.

Menurut Skelley (2010), menyatakan bahwa organisasi dibentuk oleh lingkungan institusional yang mengitarinya. Pengamatan terhadap organisasi harus dilihat sebagai totalitas symbol, bahasa, ataupun ritual-ritual yang melingkupinya. Sehingga dalam memahami sebuah prilaku organisasi tidak dapat dilakukan hanya dengan melakukan agregasi atas pengamatan terhadap prilaku individu. Justru sebaliknya, banyak penelitian tentang institusionalisme yang mengkaji seberapa besar pengaruh institusi terhadap prilaku manusia melalui aturan dan norma dibangun oleh institusi. Jadi bukan manusia yang menentukan corak institusi, melainkan institusi yang berdasarkan pada aturan dan norma itulah yang mempengaruhi prilaku individu. Jadi kesejahteraan masyarakat desa Tallambalao sangat ditentukan peranan BPD. 
Untuk menciptakan kesejahteraan maka diperlukan pengawasan BPD. Nawawi (2007), menyatakan bahwa BPD perlu menggunakan pengawasan dengan metode pengawasan langsung (direct control) dan Metode Pengawasan Tidak Langsung. Metode pengawasan langsung dilakukan dengan melindungi unit kerja yang bersangkutan. Metode pengawasan ini dapat dilakukan dengan pendekatan formal dan informal.

Meotode pengawasan tidak langsung artinya kegiatan pengawasan yang dilakukan tanpa mendatangi objek yang diawasi. Caranya mempelajari dan menganalisis segala dokumen-dokumen yang menyangkut objek yang diawasi, baik berupa laporan dari pelaksanaan pekerjaan yang sifatnya berkala, laporan hasil pemeriksaan yang diperoleh dari perangkat pengawasan langsung, suratsurat pengaduan, berita atau artikel di media, dan dokumen-dokumend lainnya. Baranta (2009), menyatakan bahwa pengawasan dapat meningkat kinerja organisasi. oragnisasi juga memberikan penilaian atas kinerja organisasi dan membantu untuk mengkoreksi masalah-masalah yang ada dalam kinerja organisasi, sekaligus mencegah terjadinya kerugian/pemborosan yang tidak diinginkan. Selain itu pengawasan juga Mempertebal rasa tanggung jawab para aktor yang terkait.

Badan Permusyawaratan Desa atau yang disebut dengan nama lain adalah lembaga yang melakukan fungsi pemerintahan yang anggotanya merupakan wakil dari penduduk desa berdasarkan keterwakilan wilayah dan ditetapkan secara demokratis. Oleh karena itu penguatan BPD dapat dilihat dengan menilai tolak ukur dari baik buruknya sebuah substansi legislasi dan dinilai dari aspek yang sesuai dengan kebutuhan dan tujuannya BPD dalam menciptakan chek and balance proses pemerintahan desa. Dalam Pasal 55 Undang-undang Nomor 6 Tahun 2014 Tentang Desa bahwa Badan Permusyawaratan Desa mempunyai fungsi membahas dan menyepakati Rancangan Peraturan Desa bersama Kepala Desa; menampung dan menyalurkan aspirasi masyarakat Desa; serta melakukan pengawasan.

\section{METODE PENELITIAN}

\subsection{Jenis Penelitian}

Jenis penelitian ini adalah penelitian deskriptif dengan menggunakan pendekatan kualitatif. Penelitian ini menggunakan analisis institusionalisme karena penelitian ini dilakukan pada suatu bagian organisasi pemerintahan desa. Pierson \& Skocpol (2008), menyatakan bahwa analisis institusional digunakan untuk mengkaji segala sesuatu dari proses legislatif, efek terhadap gerakan sosial, sampai politik hukum.

\subsection{Lokasi Penelitian}

Penelitian dilaksanakan di Desa Karyamukti Kabupaten Gorontalo dengan pertimbangan bahwa desa tersebut merupakan desa yang memiliki potensi sumber daya alam yang melimpah dan pengembangan pembangunan pada sektor publik yang baik. Di desa tersebut tersedia sarana dan prasarana pemerintahan yang lengkap, baik sarana dan prasarana pemerintah desa maupun Badan Permusyawaratan Desa (BPD), pembangunan asrama siswa desa Karyamukti di Kota Kabupaten Gorontalo dan memiliki mobil desa yang merupakan hasil dari pembangunan desa. 


\subsection{Pengumpulan Data}

Teknik pengumpulan data yag digunakan dalam penelitian yaitu dengan menggunakan wawancara mendalam, dan dokumentasi. Wawancara mendalam (Indepth Interview), yaitu teknik pengumpulan data dimana peneliti secara langsung mengadakan tanya jawab dengan Ketua BPD, Wakil Ketua BPD, Kepala Desa dan Tokoh Masyarakat di desa Karyamukti. Dokumentasi, yaitu teknik pengumpulan data yang dilakukan untuk mendokumentasikan semua data dan informasi yang diperoleh di Kantor Desa Tallambalao. Penemuan sumber data pada orang yang diwawancarai dilakukan secara purposive sampling, yaitu dipilih dengan pertimbangan dan tujuan tertentu. Informan penelitian ini adalah kepala desa, BPD, dan masyarakat.

\subsection{Analisis Data}

Menurut Norman (2009), kegiatan analisis data kualitatif mencakup pengujian, mengerutkan, mengkategorikan, mengevaluasi, membandingkan, mensintesiskan dan mengkontemplasikan data yang dikode seperti halnya interview data mentah dan data yang direkam. analisis data yang dilakukan dalam penelitian ini melalui analisis kualitatif dengan tahapan pengelolaan data yaitu penafsiran data, reduksi data, penyusunan data, pemeriksaan keabsahan data, dan menarik kesimpulan.

\section{HASIL DAN PEMBAHASAN}

Dari temuan penelitian ini ada dua jenis pendekatan dalam menampung aspirasi, yakni top down dan bottom-up. Untuk bottom-up tersedia mekanisme penjaringan pendapat dari bawah melalui forum-forum seperti koordinasi dengan oranisasi-organisasi dipedesaan. Dalam perjalanannya ide-ide masyarakat ini kemudian harus dipadukan dengan berbagai dokumen seperti pola dasar (poldas) pembangunan yang berkarakter top down. Dalam prakteknya, pendekatan top down lebih sering terjadi atas ide yang berasal dari atas mengatasnamakan masyarakat desa.

Aspirasi masyarakat pada umumnya melibatkan level bawah dalam menyuarakan aspirasi kepada BPD. Apirasi digunakan dalam pengambilan keputusan BPD disesuaikan dengan kondisi masyarakat. Pengambilan keputusan dilakukan melalui pertemuan yang melibatkan masyarakat, kepala desa dan BPD. Hal ini menandakan bahwa partisipasi masyarakat merupakan hal mendasar dalam proses pembahasan peraturan desa. Hal ini menandakan bahwa partisipasi masyarakat merupakan hal mendasar dalam proses pembahasan peraturan desa. Adapun dimensi partisipasi masyarakat di desa Karyamukti terdiri atas dua dimensi, yaitu dimensi keluar dan dimensi kedalam. Dimensi keluar berkaitan dengan pelibatan desa dalam pembuatan keputusan tentang desa. Mulai level pemerintahan yang lebih tinggi sampai level pemerintah Kecamatan Tammerodo Sendana. Sementara dimensi kedalam menyangkut partisipasi masyarakat desa Karyamukti terhadap jalannya pemerintahan desa.

Penelitian ini menunjukkan bahwa BPD sudah mulai ada peran, tetapi belum maksimal menampung dan menyalurkan aspirasi masyarakat karena BPD menggunakan caranya sendiri yaitu mengguakan system pembagian wilayah dan semua anggotanya bertanggung jawab pada wilayah masing-masing dalam menerima aspirasi masyarakat Desa. Pada tabel 1 menunjukkan kemampuan BPD dalam mengelola aspirasi masyarakat dalam pembuatan 
peraturan desa tentang APBDes di desa Karyamukti 66,67 persen informan menyatakan kurang mampu. Karena proses pembuatan perdes lebih banyak berpedoman pada asumsi BPD dan kepala desa, dibandingkan berpedoman pada kondisi masyarakat desa yang sebenarnya. Kondisi tersebut membuat antara kepala desa dan BPD masing-masing memainkan perannya dalam menyalurkan aspirasi masyarakat kedalam perdes. Akibatnya, fungsi BPD menjadi macet dan terjadi konspirasi antara kepala desa dan BPD dalam pembuatan peraturan desa sulit diantisifasi. Jadi, demokrasi desa tetap saja sekedar simbol, belum menyentuh realitas yang sesungguhnya.

\begin{tabular}{lc} 
Tabel 1. Tanggapan informan terhadap kemampuan BPD & mengelola aspirasi \\
\hline \multicolumn{1}{c}{ Penilaian } & Persen \\
\hline Sangat mampu & - \\
Mampu & 16,67 \\
Kurang mampu & 66,66 \\
Tidak mampu & 16,67 \\
\multicolumn{1}{c}{ Total } & $\mathbf{1 0 0}$ \\
\hline
\end{tabular}

Sumber: Hasil olah data primer 2015.

Menurut Wulandari menyatakan peranan BPD dalam melaksanakan tugas pokok dan fungsinya dalam menampung dan menyalurkan aspirasi walaupun belum sepenuhnya semua aspirasi dijadikan peraturan desa. Salim juga menyatakan bahwa peranan BPD telah melaksanakan tugas pokok dan fungsinya dalam menampung dan menyalurkan aspirasi walaupun belum sepenuhnya semua aspirasi dijadikan peraturan desa. BPD merupakan suatu organisasi ditingkat desa yang berada dalang lingkup sosial yang segala tindakannya memiliki tujuan tertentu. Belum maksimalnya BPD dalam menampung dan menyalurkan aspirasi masyarakat desa menjadi sebuah kebijakan karena pengaruh persinggungan BPD dengan Kepala desa.

Akibat persinggungan menyebabkan hubungan kurang baik antara Ketua BPD dengan kepala desa menyebabkan pengambilan keputusan di desa Karyamukti menjadi kurang maksimal. Padahal adanya BPD di desa Karyamukti dapat menciptakan check and balance dalam mengelola aspirasi masyarakat dengan baik. Namun kenyataan menunjukkan bahwa BPD belum bisa memengelola aspirasi sesuai harapan masyarakat. Oleh karena itu masyarakat mendorong agar BPD dapat mengelola aspirasi masyarakat dengan baik. Karena selama ini BPD dinilai masyarakat masih belum maksimal menyalurkan aspirasi masyarakat kedalam peraturan desa Karyamukti.

Lemahnya kemampuan BPD karena BPD tidak ada kegiatan yang dilakukan dalam mengelola aspirasi. Pada tabel 2 menunjukkan bahwa BPD dinilai kurang memiliki kemampuan sumber daya manusia dari tingkat pendidikan formal karena 4 orang SMA dan 1 orang SMP. Karena itu BPD dinilai masih lemah dalam mengelola aspirasi masyarakat desa Karyamukti. Upaya peningkatan kemampuan BPD dapat dilakukan melalui peningkatan kualitas, professional dan komitmen dalam melaksanakan tugas. Untuk mewujudkan hal tersebut maka BPD desa Karyamukti dapat melakukan upaya yang memberikan kesempatan kepada semua anggota BPD untuk meningkatkan dan mengembangkan kualitas dirinya, antara lain dengan mengikuti pendidikan dan pelatihan. 
Tabel 2. Tingkat Pendidikan Formal Anggota BPD di Desa Karyamukti

\begin{tabular}{cc}
\hline Nama & Pendidikan \\
\hline Hasbi P & SMA \\
Rusdi K & SMA \\
Hirman & SMP \\
Sudirman & SMA \\
Rohana & SMA \\
\hline
\end{tabular}

Sumber: Hasil Olah data Sekunder, 2017

Pendidikan merupakan sebuah proses transformasi suatu pengetahuan dari seseorang kepada orang lain secara sistematis dan pembinaan yang bersifat mendasar. Dengan kata lain merupakan upaya mendorong perkembangan cara berpikir serta merangsang pertumbuhan pola pikir BPD. Adanya tugas BPD yang kompleks, maka faktor pendidikan mutlak dibutuhkan karena pendidikan dapat mengubah cara betindak dan cara hidup dimasyarakat. Disampin itu BPD perlu terlibat secara aktif untuk mengikuti pelatihan-pelatihan teknis, diskusi, seminar yang relevan dengan fungsinya yang dilaksanakan oleh lembagalembaga lainnya. Pendidikan dan pelatihan dapat meningkatkan insiatif dan keahlian anggota BPD dalam melaksanakan fungsinya, baik dimasa sekarang maupun dimasa mendatang.

Untuk memaksimal fungsi BPD dalam membahas dan menyepakati ranperdes menurut Scott perlu dikembangkan tiga pilar dalam tatanan sebuah kelembagaan BPD, yaitu regulatif, normatif, dan kognitif. Pilar regulatif menekankan pada aturan dan pengaturan sanksi, pilar normatif mengandung dimensi evaluatif dan kewajiban, sedangkan pilar kognitif melibatkan konspesi bersama dan frame yang menempatkan pada pemahaman oleh BPD. Setiap pilar tersebut meberikan alasan yang berbeda dalam hal legitimasi BPD, baik yang berdasarkan sanksi hukum, secara kewenangan moral dan dukungan budaya. Dengan adanya tiga pilar tersebut maka kedudukan BPD di desa Karyamukti dapat berjalan dengan baik.

Tabel 3. Tanggapan informan terhadap kemampuan BPD dalam mengundangkan perdes di desa Karyamukti.

Penilaian Persen

\begin{tabular}{lc}
\hline Sangat mampu & - \\
Mampu & - \\
Kurang mampu & 66,67 \\
Tidak mampu & 33,23 \\
\multicolumn{1}{c}{ Total } & $\mathbf{1 0 0}$ \\
\hline
\end{tabular}

Sumber : Hasil olah data primer 2017

Selain lemah dalam mengelola aspirasi, BPD juga belum mampu membuat rancangan, membahas dan mengundangkan peraturan desa dengan benar disebabkan kurangnya kemampuan SDM dan kurang efektifnya organisasi BPD dalam proses pembuatan peraturan desa Karyamukti. Ketidak mampuan BPD diakibatkan karena kemampuan BPD begitu terbatas dalam mengetahui substansi yang akan diundangkan kedalam peraturan desa. Pada tabel 3 menunjukkan bahwa BPD di desa Tallambalao 66,67 persen informan 
menyatakan kurang mampu dalam mengundangkan peraturan desa bersama kepala desa. Dimana hanya dapat membentuk 1 peraturan desa setiap tahun sejak tahun 2010 sampai pada tahun 2016 yaitu peraturan desa tentang anggaran pendapatan dan belanja desa Karyamukti. Oleh karena itu BPD memerlukan pembinaan dalam bidang pembuatan perundang-undangan sehingga aturan dapat menciptakan kesejahteraan masyarakat desa. Menurut Natabaya menyatakan bahwa menilai kualitas peraturan perundang-undangan harus dilihat dari hulu sampai hilir.

Proses BPD dalam pembuatan kebijakan ditingkat desa menurut Kusandajani menyatakan bahwa proses pengambilan keputusan dilakukan melalui proses musyawarah antara BPD, kepala desa, dan masyarakat. Proses tersebut dilaksanakan setiap tahun dan dilaksanakan kantor desa melalui musyawarah pembangunan desa (musbangdes). Musbangdes bertujuan untuk merumuskan peraturan desa Karyamukti. Peraturan Desa adalah produk hukum tingkat desa yang ditetapkan melalui proses politik oleh Kepala Desa bersama Badan Permusyawaratan Desa dalam rangka penyelenggaraan pemerintahan desa. Peraturan desa merupakan penjabaran lebih lanjut dari peraturan perundang-undangan yang lebih tinggi dengan memperhatikan kondisi sosial budaya masyarakat desa setempat. Kesejahteraan masyarakat dapat dicapai apabila kondisi social dan budaya masyarakat dapat dapat melakukan pengawasan secara maksimal dalam pembangunan dan penyelenggaraan pemerintahan desa.

Untuk menciptakan kesejahteraan maka diperlukan pengawasan BPD. Menurut Nawawi menyatakan bahwa BPD perlu menggunakan pengawasan dengan metode pengawasan langsung (direct control) dan Metode Pengawasan Tidak Langsung. Metode pengawasan langsung dilakukan dengan melindungi unit kerja dari BPD itu sendiri. Pengawasan ini dapat dilakukan dengan mempelajari dan menganalisisi berbagai informasi dan data sebagai bahan masukan yang meneggambarkan berbagai kegiatan yang hendak diketahui efektifitas dan efisiensi pelaksanaan oleh BPD. Metode ini bisa dilakukan dengan wawancara langsung kepada pelaksana kegiatan atau orang lain yang dianggap mengetahui dengan baik pelaksanaan kegiatan tersebut. Dengan demikian metode pengawasan BPD dapat dilakukan dengan pendekatan formal dan informal. Pengawasan formal adalah pengawasan yang dilakukan oleh pejabat instansi yang berwenang baik bersifat eksternal maupun internal. Pengawasan informal adalah pengawasan yang dilakukan masyarakat, misalnya dengan media massa dan lembaga-lembaga swadaya masyarakat ataupun melalui suratsurat pengaduan.

Pengawasan sistem pemerintah desa merupakan suatu usaha penertiban untuk menjamin terealisasi segala ketentuan Undang-undang dan ketentuan daerah itu sendiri. Tujuan pengawasan adalah agar hasil pekerjan dapat berdaya guna dan berhasil guna sesuai dengan perencanaan. BPD belum dapat melakukan pengawasan kinerja kepala desa secara maksimal karena terbatasnya regulasi yang menjadi pedoman bagi BPD dan kurangnya kemampuan sumber daya manusia anggota BPD dibidang pengawasan. Pada tabel 5 menunjukkan bahwa kemampuan BPD dalam mengawasi kinerja kepala desa Karyamukti masih lemah karena 50 persen informan menyatakan kurang mampu dan 50 persen lagi informan menyatakan tidak mampu. Hal itu dapat dilihat dari beberapa potensi sumber daya alam desa Karyamukti belum dapat 
dikelola dengan menggunakan peraturan desa. Selain itu, pengawasan BPD juga lemah dalam menjaga dan memperkuat nilai-nilai kearifan lokal sebagai kekuatan utama dalam proses demokrasi dipedesaan. Dapat dilihat dari terjadinya pergeseran nilai-nilai kearifan local dipedesaan akibat pengaruh tatanan politik pedesaan. Tatanan politik pedesaan telah merusak tatanan desa, sehingga desa kehilangan karakter kearifan lokal.

\begin{tabular}{lc}
$\begin{array}{l}\text { Tabel 5. Tanggapan informan terhadap kemampuan } \\
\text { kinerja kepala desa Karyamukti. } \\
\text { Penilaian }\end{array}$ & Persen \\
\hline \multicolumn{1}{c}{ Palam } & - \\
\hline Sangat mampu & - \\
Mampu & 50 \\
Kurang mampu & 50 \\
Tidak mampu & $\mathbf{1 0 0}$ \\
\multicolumn{1}{c}{ Total } &
\end{tabular}

Sumber : Hasil olah data primer 2017

Pengawasan kinerja kepala desa yang dilakukan BPD belum menunjukkan adanya jaminan dapat memenuhi harapan masyarakat. BPD belum mampu menganalisis dan mengurai anggaran ranperdes dengan benar. Hal inilah yang membuat BPD masih didominasi oleh kepala desa ketika pembahasan anggaran, sehingga pengawasan BPD terhadap kinerja kepala desa masih lemah. Dalam melakukan penguatan proses pengawasan yang perlu dipersiapkan oleh BPD, yaitu Menetapkan beberapa jenis standar atau sasaran, Mengukur dan membandingkan kenyataan yang sebenarnya terhadap standar. BPD juga perlu melakukan Identifikasi penyimpangan dan pengambilan tindakan korektif. Rangkaian tindakan yang tercakup dalam proses pengawasan terebut merupakan tindakan untuk menetapkan standar pengawasan.

Pengawasan BPD terhadap pelayanan dan penggunaan anggaran desa Karyamukti dapat ditingkatkan. kendala penguatan BPD karena belum ada payung hukum yang jelas mengatur pengawasan BPD, sehingga ketika ada masalah hanya dapat dibicarakan melalui musyawarah bersama dengan kepala desa dan tokoh masyarakat. Perlu adanya penguatan pengawasan BPD dalam menilai kinerja melalui pembinaan secara intensif yang dilakukan oleh instansi pemerintah yang berhubungan dengan pemerintahan desa. Penguatan dapat melalui pendidikan dan pelatihan, work shop, dan bimbingan teknis. Menurut Baranta menyatakan bahwa pengawasan dapat meningkatkan kinerja organisasi BPD. BPD dapat memberikan penilaian atas kinerja organisasi dan membantu untuk mengkoreksi masalah-masalah yang ada dalam kinerja organisasi, sekaligus mencegah terjadinya kerugian/pemborosan yang tidak diinginkan. Selain itu pengawasan juga Mempertebal rasa tanggung jawab para aktor yang terkait.

\section{PENUTUP}

Hasil penelitian ini disimpulkan: Pertama, BPD telah melaksanakan fungsi menampung dan menyalurkan aspirasi masyarakat, diantaranya BPD menerima aspirasi masyarakar desa Karyamukti dibidang pendidikan, agama, seni dan olah raga. Tetapi hal itu tidak menunjukkan keberhasilan yang maksimal disebabkan karena BPD belum dapat bekerja maksimal dan gaji BPD yang 
masih rendah. Kedua, BPD telah membuat rancangan, membahas dan mengundangkan peraturan desa bersama kepala desa Karyamukti, namun belum menunjukkan hasil yang maksimal disebabkan kurangnya kemampuan SDM dan kurang efektifnya organisasi BPD dalam proses pembuatan peraturan desa Karyamukti. Ketiga, BPD sudah melakukan pengawasan kinerja kepala desa Karyamukti namun belum menunjukkan pengawasan yang maksimal karena terbatasnya regulasi yang menjadi pedoman bagi BPD dan kurangnya kemampuan sumber daya manusia anggota BPD dibidang pengawasan. Penulis menyarankan agar BPD melakukan cara musyawarah usul antar dusun, kemudian dirembukkan kedalam musyawah tingkat desa. Perlu juga diberikan kesempatan kepada BPD mengkuti pendidikan dan pelatihan dalam bentuk pelatihan, work shop, seminar dan diskusi serta sistem regulasi tentang BPD segera dilengkapi.

\section{DAFTAR PUSTAKA}

Baranta Atep. (2009). Dasar- dasar Pengawasan. Jakarta: Elex Media Komputindo.

Fauzan Ali. (2010). Implementasi peraturan pemerintah Nomor 72 tahun 2005 tentang desa Terkait dengan peran badan permusyawaratan desa Dalam penyusunan dan penetapan Peraturan Desa Di Kecamatan Wanasari Kabupaten Brebes. The Journal Politic, 14 (5): 316-318

Kushandajani. (2008). Otonomi Desa Berbasis Modal Sosial Dalam Perspektif Socio Legal. Jakarta: PT. Golbal Media.

Natabaya HAS. (2007). Peningkatan Kualitas Peraturan Perundang-undangan; Suatu Pendekatan Input dan Output. Jurnal Legislasi Indonesia, $4(2): 176-179$.

Nawawi Hadari. (2007). Manajemen Pengawasan Melekat. Jakarta: Haji Mas Agung.

Nogi Hessel Tangkilisan. (2005). Manajemen Publik. Jakarta: Penerbit PT.Grasindo.

Norman Denzin. K. (2009). Qualitatid Reseach. Yogyakarta: Pustaka Pelajar.

Pierson \& Skocpol. (2008). Historical institusinalism in Contemporary Political Science. Dalam I. Katzenold \& H.V. Miller (ed). New York: W. W. Norton.

Salim Agus (2012). dengan topik penelitian Peranan Badan Permusywaratan Desa Dalam Penyelenggaraan Pemerintahan di Desa Kaumang Kecamatan Kaumang. Jurnal Borneo Administrator, 9(3): 223-225.

Skelley. (2010). Institutions and Organizations. Handbook of Industrial Organization: North Holland.

Svein Eng. (2009). Legislative Inflation and the Quality of Law dalam Luc J. Witngens et.al. Legisprudence: A New Theoritical Approach Of Legislation. Oregon: Hart Publishing.

Tuori Kaarlo. (2009). Legislation Between Politic and Law dalam Luc J. Witngens et.al. Legisprudence: A New Theoritical Approach Of Legislation. Oregon: Hart Publishing.

Wasistiono Kaarlo \& Tahir Irawan. (2007). Prospek Pengembangan Desa. Bandung: CV Fokus Media.

Wulandari Putri. (2011). Peranan Badan Permusywaratan Desa Dalam Penyelenggaraan Pemerintahan di Kabupaten Pinrang. Jurnal Pemerintahan Desa, 16 (2): 185-187. 